\title{
The Use of You and Thou in The Two Gentlemen of Verona
}

Fco. Javier Díaz Pérez

Universidad de Santiago de Compostela

\begin{abstract}
The aim of this paper is to analyse the different factors which determine the choice of one of the two variants of the second person singular pronoun, You or Thou, by the various characters of Shakespeare's play The Two Gentlemen of Verona. The total number of you and thou forms which constitute this corpus is 777. Each of these forms has been analyzed taking into account the social relationships of power and solidarity established between the interlocutors, as well as the variables of social class and sex. In addition, emotional factors have been considered. It is not my intention to extrapolate the results obtained in this study to the English usage of Shakespeare's age. They simply refer to the play itself.
\end{abstract}

\section{Introduction}

Present-day English, as opposed to most languages of its environment, has an only pronominal form for the second person singular. It is, therefore, impossible to mark different degrees of formality or familiarity with an interlocutor by means of pronominal usage. Nevertheless, this has not been always the case, since in earlier periods English distinguished two forms, you and thou, for the second person singular pronoun. As Catalina Weinerman states in her work Sociolingüística de la forma pronominal, "las formas de la segunda persona del singular tienen, dentro del conjunto de los pronombres personales, un interés linguiístico particular porque vinculan las propiedades abstractas de la gramática con categorías semánticas derivadas de propiedades socioculturales" (33-34). This statement can be applied to the case of you and thou, and to show evidence of this, we will analyse the circumstances which determine the usage of one variant or the other in William Shakespeare's play The Two Gentlemen of Verona, in which, in addition to 
sociocultural aspects, it is evident that the use of you and thou is on some occasions conditioned by emotional factors. The first section of the paper concerns itself with a description of the corpus, in the second and third sections the dimensions of power and solidarity are respectively analysed, section four deals with the emotional value expressed by the second person singular pronouns and finally, the social class and sex variables are dealt with in sections five and six respectively.

\section{Description of the corpus}

Brown and Gilman consider that dramatic texts offer the best information about the colloquial language of the period. Moreover, theatrical plays constitute, according to these authors, the only possible source, since, although there are also letters, these cannot inform us about oral and colloquial language ("Politeness Theory" 170). Jonathan Hope, however, thinks that the use of you and thou in Shakespeare's plays does not reflect the real usage of the English spoken in the Early Modern period (142). Salmon, in justifying the use of theatre works in her analysis of sentence structures in Elizabethan colloquial English, says that we can only resort to "the language written to be uttered as though spontaneously arising from a given situation which we find in dramatic texts" (265). In any case, whether Shakespeare's plays are a loyal reflection of the colloquial language of his age or not, the play chosen for this study has been The Two Gentlemen of Verona due to the fact that its characters represent different social strata. Moreover, the multiplicity of changes from you to thou and viceversa makes of this text a very appropriate object for the study and exemplification of the factors which condition the selection of the pronominal variant. In addition to this, nobody can deny Shakespeare's mastery in language management, which guarantees that the shifts from one pronominal form to the other are significantly motivated. However, it is not my intention to extrapolate the results obtained in this study to the English usage of the age.

Seven hundred and seventy-seven cases have been found in the play in which one of the variants is used. In addition to you and thou, I have also counted the variant ye, the oblicuous form thee, the possessives yours and thine, the intensive and reflexive pronouns yourself and thyself, and the determiners your, thine and thy. The reason is that all these forms behave in the same way, since if in a speech or in a passage a character uses regularly thou to address another character, he or she will also normally employ thee, thine, thy and thyself. By convention, I will use You and Thou, with capital letters, to refer not only to these forms, but also to their respective associated forms. Obviously, I have not considered the forms you with plural referent. Those second person singular pronouns which referred to an inanimate object or to an indefinite being have not been included in the corpus either. The number of $y$ forms found in The Two Gentlemen of Verona is, as can be seen in Table 1, 466, which represent $59.97 \%$ of the total number of second person singular pronominal forms. Thou, on the other hand, constitutes $40.03 \%$, with 311 cases. 


\begin{tabular}{|c|c|c|c|c|c|}
\hline \multicolumn{2}{|c|}{ Y O U } & \multicolumn{2}{c|}{ TH O U } & \multicolumn{2}{|c|}{ T O T A L } \\
\hline \hline $\mathbf{N}$ & $\%$ & $\mathbf{N}$ & $\%$ & $\mathbf{N}$ & $\%$ \\
\hline 466 & 59.97 & 311 & 40.03 & 777 & 100 \\
\hline
\end{tabular}

Table 1. Distribution of the variants You and Thou in The Two Gentlemen of Verona

\section{The social dimension of power}

I will first deal with the dimension which Brown and Gilman have named "power semantic" in their article "The Pronouns of Power and Solidarity" and which they have defined in the following terms:

One person may be said to have power over another in the degree that he is able to control the behaviour of the other. Power is a relationship between at least two persons, and it is nonreciprocal in the sense that both cannot have power in the same area of behaviour. The power semantic is similarly nonreciprocal; the superior says $\mathrm{T}$ and receives $\mathrm{V}(255){ }^{1}$

The power dimension accounts for a relationship of verticality in the social hierarchy and it is therefore linked to the variable of social class. Three social classes can be distinguished in this play: high, middle and low. In the high class, the characters have different degrees of power. The pronoun predominantly used by the members of this social class is You, with 278 cases, which represent $56.67 \%$ of the total. Thou is employed on 240 occasions, which account for $46.33 \%$. When both interlocutors belong to the high class, as Table 2 displays, You is the most frequent pronoun with 237 occurrences and $57.11 \%$, as opposed to 178 cases in which Thou appears, which represent $42.89 \%$. However, it is necessary to make a distinction here depending on the different interlocutors. When the speaker's power is inferior to that of the listener, the former will employ mostly You to address the latter. While Thou is used on 60 occasions (84.51\%), You appears in 11 examples $(15.49 \%)$. If the level of power is equivalent or similar, although You is still the dominant form $(146$ cases $=56.59 \%$ ), the usage of Thou is not infrequent at all ( 112 cases= $43.41 \%$ ). If the power of the speaker is superior to that of the listener, the use of Thou is, conversely, superior to that of You: 31 you-forms (36.05\%) and 55 thou-forms (63.95\%). When a high class character addresses a low class one (See Table 3), in which case the speaker's power is obviously superior to the listener's one, he will do it using mainly Thou, with 40 registered examples. While in the previous cases Thou was the marked form, now this role belongs to You, with $46.67 \%$ and 35 examples. 


\begin{tabular}{|c|c|c|c|c|c|c|c|c|c|c|c|}
\hline \multicolumn{12}{|c|}{ HIGH CLASS --> HIGH CLASS } \\
\hline \multicolumn{4}{|c|}{ + TO - POWER } & \multicolumn{4}{|c|}{ = POWER } & \multicolumn{4}{|c|}{ - TO + POWER } \\
\hline \multicolumn{2}{|c|}{ YOU } & \multicolumn{2}{|c|}{ THOU } & \multicolumn{2}{|c|}{ YOU } & \multicolumn{2}{|c|}{ THOU } & \multicolumn{2}{|c|}{ YOU } & \multicolumn{2}{|c|}{ THOU } \\
\hline $\mathbf{N}$ & $\%$ & $\mathbf{N}$ & $\%$ & $\mathbf{N}$ & $\%$ & $\mathbf{N}$ & $\%$ & $\mathbf{N}$ & $\%$ & $\mathbf{N}$ & $\%$ \\
\hline 31 & 36.05 & 55 & 63.95 & 146 & 56.59 & 112 & 43.4 & 60 & 84.5 & 11 & 15.48 \\
\hline \multicolumn{12}{|c|}{ TOTAL } \\
\hline \multicolumn{6}{|c|}{ YOU } & \multicolumn{6}{|c|}{ THOU } \\
\hline \multicolumn{3}{|c|}{$\mathbf{N}$} & \multicolumn{3}{|c|}{$\%$} & \multicolumn{3}{|c|}{$\mathbf{N}$} & \multicolumn{3}{|c|}{$\%$} \\
\hline \multicolumn{3}{|c|}{237} & \multicolumn{3}{|c|}{57.11} & \multicolumn{3}{|c|}{178} & \multicolumn{3}{|c|}{42.89} \\
\hline
\end{tabular}

Table 2. Use of You and Thou between high class characters.

\begin{tabular}{|c|c|c|c|}
\hline \multicolumn{3}{|c|}{ HIGH CLASS ---> LOW CLASS } \\
\hline \hline \multicolumn{2}{|c|}{ Y O U } & \multicolumn{2}{|c|}{ T H O U } \\
\hline NUMBER & PERCENTAGE & NUMBER & PERCENTAGE \\
\hline 35 & 46.67 & 40 & 53.33 \\
\hline
\end{tabular}

Table 3. Use of You and Thou by high class characters towards low class characters.

Those characters who belong to a low stratum, as Table 4 reflects, generally make use of the th forms to address their equals ( 60 Thou forms $=82.24 \%$ and 8 You forms= $11.76 \%$ ). On the other hand, when low class members, maids and servants, address their superiors in the social scale, they always use the form You, except on one occasion (131 You forms: $99.24 \%$ and 1 Thou form: $0.76 \%$ ).

\begin{tabular}{|c|c|c|c|c|c|c|c|c|c|c|c|}
\hline \multicolumn{4}{|c|}{ LOW ---> LOW } & \multicolumn{4}{|c|}{ LOW ---> HIGH } & \multicolumn{4}{|c|}{ TOTAL } \\
\hline \multicolumn{2}{|c|}{ YOU } & \multicolumn{2}{|c|}{ THOU } & \multicolumn{2}{|c|}{ YOU } & \multicolumn{2}{|c|}{ THOU } & \multicolumn{2}{|c|}{ YOU } & \multicolumn{2}{|c|}{ THOU } \\
\hline $\mathbf{N}$ & $\%$ & $\mathbf{N}$ & $\%$ & $\mathbf{N}$ & $\%$ & $\mathbf{N}$ & $\%$ & $\mathbf{N}$ & $\%$ & $\mathbf{N}$ & $\%$ \\
\hline 8 & 11.8 & 60 & 82.2 & 131 & 99.24 & 1 & 0.76 & 191 & 95.5 & 9 & 4.5 \\
\hline
\end{tabular}

Table 4. Use of You and Thou by low class characters.

As these data display, while the high class members have a great freedom to use any of the two forms, the representatives of the low class are submitted to a much more rigid 
rule. Although masters generally address their servants by means of Thou, they could also use You to them, and, in fact, as we have seen, in this play this is quite a frequent practice. Servants, conversely, almost invariably used You to address their masters, since the use of Thou to refer to a social superior was considered a great lack of respect.

\section{Solidarity}

According to Brown and Gilman, solidarity is the second dimension which conditions the use of the pronouns of address. While power constituted the vertical axis of social relationships, solidarity is conceived as the horizontal one. It is a feeling of sympathy and comprehension, a group of shared ideas, traits and values which identify and link together groups of people, without taking into account their social status. According to Brown and Gilman, "Solidarity is symmetrical. The corresponding norms of address are symmetrical or reciprocal with V becoming more probable as solidarity declines" ("Pronouns" 258). Thus, the norms of address prescribe the reciprocal usage of the intimate informal Thou between solidary people and of the distant formal You between people who are not so. Let us see how solidarity governs pronominal address in the play with which this study is concerned.

The Two Gentlemen of Verona deals with the Renaissance ideal of friendship and it thus offers very clear expressions of solidarity. The strong link of friendship and the affinities between Protheus and Valentine, the two protagonists of this play, constitute the reason why at the beginning of the play they reciprocally address each other using Thou:

\footnotetext{
VALENTINE: Cease to persuade, my loving Protheus;

Home-keeping youth, have ever homely wits,

Wer't not affection chains thy tender days

To the sweet glances of thy honoured Love,...

PROTHEUS: Wilt thou be gone? Sweet Valentine adieu,

Think on thy Protheus, when thou (haply) seest

Some rare note-worthy object in thy travel.

Wish me partaker in thy happiness,... (T.1.21) ${ }^{2}$
}

Another case in which solidarity regulates pronominal address in this play can be found in those scenes in which the Outlaws speak to Valentine. Valentine has been banished from Milan and the Outlaws appear on his way. In the beginning, as the rules of social behaviour indicate, they use You to address Valentine, because he is a stranger and because his social class is apparently superior to theirs:

3 OUTLAW: Stand sir, and throw us that you have about ye.

If not: we'll make you sit, and rifle you....

1 OUTLAW: That's not so, sir: we are your enemies....

2 OUTLAW: Whither travel you? (IV.1.71) 
However, when they find out that Valentine, like them, has been banished and that all of them belong to the same social class, since they all are knights who have been victims of misfortune, a link of solidarity is created between them and Valentine, which is based upon their affinities. This leads them to address him as Thou from that moment onwards:

3 OUTLAW: What say'st thou? wilt thou be of our consort?

Say ay, and be the captain of us all:

We'll do thee homage, and be rul'd by thee,

Love thee, as our Commander, and our King (IV.2.72).

Apart from these two cases, there is hardly any other in which the dimension of solidarity is the determinant factor which governs the use of the second person singular pronoun. Brown and Levinson consider that the members of the low strata of a society like that reflected in this play were necessarily quite interdependent, in such a way that solidarity relationships were likely to emerge among them (332-333). According to this, the interchange of Thou between low class characters can be motivated by a combination of the dimensions of power and solidarity. On the other hand, between lovers, like Silvia and Valentine, the pronoun employed is generally You, which indicates a preponderance of power over solidarity. The same happens with parental-filial relationships, since the Duke as well as Antonio address their respective children, Silvia and Protheus, as Thou and You alternatively, but they always receive You from them. This fact is an indication that familiar relationships were in that society much more hierarchized than they are today:

SILVIA: Perchance you think too much of so much pains?

VALENTINE: No (Madam) so it stead you; I will write.

(Please you command) a thousand times as much (II.1.37).

ANTONIO: How now? What Letter are you reading there?

PROTHEUS: May'st please your Lordship, 'tis a word or two...

ANTONIO: ... I am resolv'd that thou shall spend some time

With Valentinus, in the Emperor's Court:...

PROTHEUS: My Lord I cannot be soon provided,

Please you deliberate a day or two (I.3.32-33).

Brown and Gilman state that "The solidarity $T$ reaches a peak of probability in address between two brothers or in a man soliloquizing with himself" ("Pronouns" 258). In this connection, there are two scenes in the play in which this summit of solidarity is reached. On both occasions there is a character who addresses him or herself and uses the form Thou. The first of these soliloquies is performed by Julia:

JULIA: ... unkind Julia,

As in revenge of thy ingratitude,

I throw thy name against the bruising stones,

Trampling contemptously on thy disdain (1.2.29). 
Afterwards, it will be Valentine who will address himself by means of the thou (thee on this occasion) of the highest solidarity:

VALENTINE: ... Withdraw thee Valentine: who's this coming here? (V.4.90).

\section{Emotional value}

Sometimes the choice of a pronominal form contradicts the social norm or the speaker's habitual practice. In those cases, the motivation for this will probably be connected with some attitude or emotion on the part of the speaker. These types of variations in the linguistic behaviour generally express transient feelings or attitudes. Two types of expressive meanings are distinguished. Breaking the norms of address implies that the speaker temporarily thinks about the other as a stranger or as someone related. In this connection, the emotional use of Thou can express endearment, intimacy, tenderness, as well as all the opposite, anger or contempt. Curiously enough, there are situations in which You can become the hostile or abusive form, as will be seen afterwards. According to Jespersen, in English there was a greater alternation between the two variants of the second person singular pronoun than in other European languages (28). Wales coincides in this appreciation:

the fact remains that in English usage, right from the beginning, there was always considerable fluctuation between $\mathrm{T}$ and $\mathrm{V}$ forms in the singular, whereas in French and German, even today, momentary shifts are rare. (114).

In Shakespeare's plays the quick shifts between You and Thou are extremely frequent, and in this sense, The Two Gentlemen of Verona is not an exception. On numerous occasions the same character fluctuates between the use of Thou and You with the same interlocutor. The exchanges between Protheus and Valentine are very useful to study and illustrate the expressive or emotional value of the pronouns of address. As has already been seen, in the beginning Protheus and Valentine address each other as Thou, which reflects their high degree of solidarity. Thou is the habitual unmarked form between them. However, after having been using the $t h$ form, some lines below, Valentine unexpectedly addresses his friend as You. Their disparity of opinions about love provokes the change in address from the solidary Thou to the distant You:

VALENTINE: "Tis true; for you are over-boots in love, and yet you never swom the Hellespont (T.1.21).

As Brown and Gilman point out, the fundamental characteristic of this emotional pronominal change is its easy retractibility ("Politeness Theory" 178). Thus, once they have expressed their divergent points of view, Protheus and Valentine return to their habitual Thou: 
PROTHEUS: And thither will I bring thee Valentine.

VALENTINE: Sweet Protheus, no: Now let us take our leave:

To Milan let me hear from thee by letters

Of thy success in love, and what news else

Betideth here in absence of thy Friend

And I likewise will visit thee with mine (I.1.22-23).

Although the fact that Valentine and Protheus address each other as Thou is generally motivated by their relationship of solidarity, when Valentine discovers that he has been betrayed by his friend, the Thou he uses to address him has a very different motivation. In this case, Thou expresses the fury that Valentine feels when he realizes that he has been deceived. The content of his words and the adjectives he employs to refer to Valentine, like ruffian or treacherous, indicate which is the true value of Thou here:

VALENTINE: Ruffian: let go that rude uncivil touch,

Thou friend of an ill fashion....

VALENTINE: Thou common friend, that's without faith or love,

For such is a friend now: treacherous man,

Thou hast beguil'd my hopes;... (V.4.91).

This fluctuation of pronominal forms does not only happen between the two protagonists. Thus, for instance, when Silvia, who generally addresses Protheus by means of the polite You, wants to show her contempt in front of the latter's pretensions and treasons, she uses an unequivocally scornful Thou:

SILVIA: Thou subtle, perjur'd false, disloyal man:

Think'st thou I am so shallow, so conceitless,

To be seduced by thy flattery,

That hast deceiv'd so many with thy vows?

Return, return and make thy love amends:

For me (by this pale queen of night I swear)

I am so far from granting thy request,

That I despise thee, for thy wrongful suit;... (IV.2.76).

In other scenes in which the emotional temperature is high, the use of the th form expresses just the opposite, endearment and affection. Thus, at a moment of great emotional tension, such as the farewell between Julia and Protheus, these two characters use Thou, a symbol of the love they feel for each other:

JULIA: If you turn out: you will return the sooner:

Keep this remembrance for thy Julia's sake....

PROTHEUS: Here is my hand for my true constancy:

And when that o'erslips me in the day,

Wherein I sigh not (Julia) for thy sake,...

The tide is now; nay, not thy tide of tears, 
That tide will stay me longer than I should, Julia, farewell... (II.2.39-40).

The Duke, who had shown his contempt for Valentine addressing him as Thou, finally realizes that he was mistaken and becomes reconciled with him. To show the affection that he now feels for Valentine, he addresses him by means of a respectful, affectionate and in a sense fatherly Thou:
DUKE: ... I do applaud thy spirit, Valentine, And think thee worthy of an Empress' love:
Know then, I here forget all former griefs, Cancel all grudge, repeal thee home again, Plead a new state in thy unrivall'd merit, To which I thus subscribe: Sir Valentine, Thou art a Gentlemen, and well deriv'd
Take thou thy Silvia, for thou hast desrv'd her (V.4.94).

As Brook states, one of the uses of Thou in Shakespeare's plays is that masters make of it to address their servants as an indication of a kind superiority (74). However, when a master considers that his servant has acted in a bad way and wants to show his anger and irritation, the pronoun used to address the servant is You. In this connection, Protheus, after having addressed his new servant Sebastian as Thou, uses You to his other servant, Launce, as an indication of his bad-tempered state for Launce's long and unjustified absence:

PROTHEUS: Sebastian is thy name: I like thee well, And will employ thee in some service presently...

PROTHEUS: (to Launce) How now you whoreson peasant, Where have you been these two days loitering? (IV.4.81).

Barber says that in these cases the pronoun You has an ironic nuance. When You is used in this way, it is specially frequent for the servant to receive the burlesque address of sir or sirrah, defined by Barber as "mock-polite vocatives" (Early Modern English 207). In the following example, Valentine uses this ironic You to address his servant Speed:

VALENTINE: (to Speed) How now Sir?

What are you reasoning with yourself? (II.1.38).

These are the main emotional uses of You and Thou. Comparatively, Thou acquires this emotive value much more frequently than You. As can be seen on Table 5, out of the 311 thou-forms, $102(32.80 \%)$ appear in situations with a high emotional tension, whereas only $15.24 \%$ of the you-forms, 71 out of the 466 , are an expression of emotional aspects. 


\begin{tabular}{||c|c|c|c|c|c|c|c|}
\hline \multicolumn{3}{|c|}{ Y O U } & \multicolumn{3}{c|}{ T H O U } \\
\hline \begin{tabular}{|c|c|c|c|c|c||} 
EMOTIONAL \\
VALUE
\end{tabular} & \multicolumn{2}{|c|}{ TOTAL } & \multicolumn{2}{|c|}{$\begin{array}{l}\text { EMOTIONAL } \\
\text { VALUE }\end{array}$} & \multicolumn{2}{c|}{ TOTAL } \\
\hline N & $\%$ & N & $\%$ & N & $\%$ & N & $\%$ \\
\hline 71 & 15.24 & 466 & 100 & 102 & 32.80 & 311 & 100 \\
\hline
\end{tabular}

Table 5. Emotional value and the two 2nd sing. pronoun variants.

\section{Sex variable}

The interlocutors' sex does not seem determinant in the use of one variant or the other. The literature on the topic of pronouns of address does not generally refer to this variable. From the point of view of the speaker, the pronominal uses of men and women are very similar, although Thou is slightly more used by women. As Table 6 shows, out of 162 second singular pronouns employed by women, there are 71 thou-forms, which represent $43.83 \%$ and 91 you-forms (56.17\%). Men use Thou on 240 occasions (39.02\%), as opposed to 375 on which they use You $(60.98 \%)$. From the point of view of the listener, the difference is much more noteworthy, since whereas in the pronouns addressed to men $54.35 \%$ are you-forms (337) and $45.65 \%$ thou-forms (283), when the listener is a woman, only in $17.83 \%$ of the cases Thou is used, with 28 registered forms, as opposed to $82.17 \%$ in which You is employed, which corresponds to 129 instances. These data seem to imply, therefore, that Thou is a less appropriate form to address a woman than a man.

\begin{tabular}{|c|c|c|c|c|c|c|c|c|c|c|c|c|}
\hline \multicolumn{4}{|c|}{ WOMAN } & \multicolumn{8}{c|}{ MAN } \\
\cline { 2 - 11 } & \multicolumn{2}{|c|}{ Y O U } & \multicolumn{2}{|c|}{ T H O U } & TOTAL & \multicolumn{2}{c|}{ Y O U } & \multicolumn{2}{c|}{ T H O U } & \multicolumn{2}{c|}{ TOTAL } \\
\hline N & $\%$ & $\mathbf{N}$ & $\%$ & $\mathbf{N}$ & $\%$ & $\mathbf{N}$ & $\%$ & $\mathbf{N}$ & $\%$ & $\mathbf{N}$ & $\%$ \\
\hline speaker & 91 & 56.17 & 71 & 43.83 & 162 & 100 & 375 & 60.98 & 240 & 39.02 & 615 & 100 \\
\hline listener & 129 & 82.17 & 28 & 17.83 & 157 & 100 & 337 & 54.35 & 283 & 45.65 & 620 & 100 \\
\hline
\end{tabular}

Table 6. Use of You and Thou according to the sex of addresser and addressee.

Table 7 contains the four possible combinations regarding the sex of speaker and listener. When a man addresses another man, he does it on 298 occasions by means of $Y c u$ (56.44\%), whereas on 230 cases, he employs Thou (43.56\%). Women use You to address women in $74.29 \%$ of the cases (52) and Thou in $25.71 \%$ (18 ex.). You is the predominant form used by men to address women, with $88.51 \%$ (77 ex.), while in only $11.49 \%$ Thou is used (10 ex.). Women, on the other hand, use Thou to men in $57.61 \%$ (53 ex.) and You in $42.39 \%$ ( $39 \mathrm{ex}$.). 


\begin{tabular}{|l|c|c|c|c|c|c|c|c||}
\cline { 2 - 10 } & \multicolumn{2}{l|}{$\begin{array}{l}\text { WOMAN TO } \\
\text { WOMAN }\end{array}$} & \multicolumn{2}{l|}{$\begin{array}{l}\text { MAN TO } \\
\text { MAN }\end{array}$} & \multicolumn{2}{l|}{\begin{tabular}{l}
\multicolumn{2}{l|}{ WOMAN TO } \\
MAN
\end{tabular}} & \multicolumn{2}{l|}{$\begin{array}{l}\text { MAN TO } \\
\text { WOMAN }\end{array}$} \\
\cline { 2 - 10 } & $\mathbf{N}$ & $\%$ & $\mathbf{N}$ & $\%$ & $\mathbf{N}$ & $\%$ & $\mathbf{N}$ & $\%$ \\
\hline THOU & 18 & 25.71 & 230 & 43.56 & 53 & 57.61 & 10 & 11.49 \\
\hline YOU & 52 & 74.29 & 298 & 56.44 & 39 & 42.39 & 77 & 88.51 \\
\hline TOTAL & 70 & 100 & 528 & 100 & 92 & 100 & 87 & 100 \\
\hline
\end{tabular}

Table 7. Use of You and Thou in the 4 possible combinations according to the sex of the interlocutors.

\section{Conclusions}

Although in quantitative terms, the difference between You and Thou in The Two Gentlemen of Verona is perhaps not large enough to speak of a marked and an unmarked form, we can establish that distinction if we attend to other criteria. Both You and Thou occasionally acquire an expressive or emotional value in this play, but whereas Thou has these connotations in $32.80 \%$ of the cases, the percentage with respect to You goes down to $15.24 \%$. This marked character that Thou has in the semantic level is also reflected, as Wales points out, in the linguistic level, since Thou-forms are outnumbered by You-forms, the reciprocal interchange of You is more frequent than that of Thou, and momentary changes from You to Thou are more numerous than changes from Thou to You.

As regards the factors which condition the selection of the pronominal form, the dimension of power is the most decisive one in opting for one form or the other. However, we cannot consider that the social usage is the norm and everything that does not correspond to it is a deviation which will have to be explained by means of affective or emotional reasons, since other factors, like solidarity, can play their part. It is necessary to pay attention to the form generally used between two interlocutors and to the emotional situation, since the same form used between the same speakers can have two different values. Thus, the Thou which Valentine uses to address Protheus generally reflects the relationship of solidarity between them both, but it can also express, as has been shown, fury and anger.

Finally, I want to emphasize that the aim of this study is a quantitative as well as a qualitative analysis of the use of the second person singular pronoun in The Two Gentlemen of Verona. It is not my intention to draw any generalizations about the usage of You and Thou in Shakespeare's society, since, as Wales indicates, "while it may be reasonably supposed that the usage of dialogues in drama reflects that current in society, yet allowance must also be made for literary selectiveness on the one hand, and artistic exaggeration on the other" (128). It is possible that in real life, Thou were less used, while in drama, due to its concentration of emotional tension, this variant appeared more frequently. 


\section{Notes}

$1 T$ and $V$ (from Latin $t u$ and vos) stand respectively for the familiar and the formal variants of the second person singular pronoun, in our case for Thou and You respectively.

2 Emphasis on all the second singular pronoun forms in the quotations is mine.

\section{Works cited}

Barber, Ch. Early Modern English. London: Andre Deutsch, 1976. . "Thou and You in Shakespeare's Richard III." Leeds Studies in English New Series 12 (1981): 273-280.

Brook, G. L. The Language of Shakespeare. London: Andre Deutsch, 1976.

Brown, P. and S. Levinson. "Universals in Language Use: Politeness Phenomena." Questions and Politeness. Ed. E. N. Goody. Cambridge: Cabridge University Press, 1979.

Brown, R. and A. Gilman. "The Pronouns of Power and Solitarity." Language and Social Context.

Ed. P. Giglioli. London: Penguin Books, 1960. "Politeness Theory and Shakespeare's Four Major Tragedies." Language in Society 18

(1989): 159-212.

Hope, J. "The Use of Thou and You in Early Modern spoken English: evidence from depositions in the Durham ecclesiastical court records." Studies in Early Modern English. Ed. D. Kastovsky. Berlin: Mouton de Gruyter, 1994.

Jespersen, O. Growth and Structure of the English Language. 9th ed. Oxford: Blackwell, 1972. Mullholand, J. "Thou and You in Shakespeare: A Study of the Second Person Pronoun." English Studies 48 (1967): 34-43.

Salmon, V. "Sentence Structures in Colloquial Shakespearean English." A Reader in the Language of Shakespearean Drama. Eds. V. Salmon and E. Burness. Philadelphia: John Benjamins, 1987. 265-300.

Wales, K. M. "Thou and You in Early Modern English: Brown and Gilman re-appraised." Studia Linguistica 37.2 (1983): 107-125.

Weinerman, C. Sociolingüistica de la forma pronominal. México: Trillas, 1976. 